\title{
Asphyxiation of an Endangered Cook Inlet Beluga Whale, Delphinapterus leucas
}

\author{
NATALIE ROUSE, KATHY A. BUREK-HUNTINGTON, and KIM E.W. SHELDEN
}

\section{Introduction}

The Cook Inlet beluga whale, Delphinapterus leucas, is nonmigratory, residing year-round in a semi-enclosed tidal estuary in southcentral Alaska. The population is genetically and spatially isolated from all other beluga populations (O'Corry-Crowe et al., 1997; Laidre et al., 2000). Once an important subsistence species for Alaska Natives, unregulated hunting led to a substantial decline in the Cook Inlet beluga population between 1994 and 1998 (Hobbs et al., 2000). The population has continued to decline despite a hunting moratorium and co-management agreements between the National Marine Fisheries Service (NMFS) and Alaska Native organizations that limitwith the Alaska SeaLife Center, 301 Railway Ave., Seward, AK 99664; Kathy Burek-Huntington is with Alaska Veterinary Pathology Service, 23834 The Clearing Dr., Eagle River, AK 99577; and Kim Shelden is with the Marine Mammal Laboratory, Alaska Fisheries Science Center, NMFS, NOAA, 7600 Sand Point Way N.E., Seattle, WA 98115.

doi: https://doi.org/10.7755/MFR.79.2.3
Natalie Rouse (natalier@alaskasealife.org) is

ed the hunt (Hobbs et al., 2000, 2015). In 2016, the population was estimated to be 328 whales (Shelden et al. ${ }^{1}$ ). The status of this population, with no known cause for a continued decline, elevates the need to necropsy all dead belugas for causes of mortality. NMFS developed a stranding response plan $^{2}$ for Cook Inlet belugas in 2009, authorizing necropsies of dead Cook Inlet belugas.

Methods
Study Area
Cook Inlet (Fig. 1) is a $180 \mathrm{mi}$ long,
$39,325 \mathrm{mi}^{2}$ mass of water bordering the Gulf of Alaska and adjacent to the city of Anchorage in south central Alaska. It is characterized by shallow, soft, mixed benthic sediment, mud

${ }^{1}$ Shelden, K. E. W., R. C. Hobbs, C. L. Sims, L. Vate Brattström, J. A. Mocklin, C. Boyd, and B. A. Mahoney. 2017. Aerial surveys, abundance, and distribution of beluga whales (Delphinapterus leucas) in Cook Inlet, Alaska, June 2016. AFSC Processed Rep. 2017-09, 62 p. Available at http://www.afsc.noaa.gov/ Publications/ProcRpt/PR2017-09.pdf.

${ }^{2}$ Stranding Response Plan avail. at https://alaskafisheries.noaa.gov/sites/default/files/beluga_ stranding_plan2009.pdf, accessed 25 Apr. 2016.

ABSTRACT-The isolated population of Cook Inlet beluga whales, Delphinapterus leucas, is endangered under the U.S. Endangered Species Act (ESA). They reside year-round in the Cook Inlet tidal estuary in southcentral Alaska, near Anchorage. Due to their ESA status, information on causes of mortality are important. A dead beluga was reported in Turnagain Arm, Cook Inlet, on 7 Oct. 2013, and a necropsy was performed two days later. The beluga was a robust, apparently healthy adult male $\sim 40$ years old. Cause of death was determined to be asphyxiation caused by a starry flounder, Platichthys stellatus, found lodged in the pharynx at the goose beak, dislocating the larynx. Prey anatomy such as spines, body shape, and backbone rigidity may increase the risk of choking in beluga whales and other cetaceans. This is the first known death by asphyxiation of the 49 Cook Inlet beluga deaths investigated in the last 18 years, indicating that it is rare and not likely to be a significant cause of mortality. It is important, however, to monitor and document all sources of mortality given the status of this endangered population. flats, large tidal fluctuations $(30+\mathrm{ft})$, and active seismic and volcanic contributions. Approximately 347,000 people (about half of the population of the State of Alaska) reside adjacent to Cook Inlet. Most cities and villages are located on the east side, which is accessible by both road and rail line. The west side of the inlet is sparsely populated and is only accessible by air or boat.

On 7 Oct. 2013, a beluga whale was reported stranded in Turnagain Arm (Fig. 1). Weather prohibited examination until 9 Oct. 2013, when the carcass was accessed by helicopter and approached on foot. The carcass had moved west of the original stranding location, presumably having floated and re-stranded on the outgoing tide.

\section{Examination and Sample Collection}

The examination included external, subcutaneous, respiratory, digestive, lymphoid, urogenital, reproductive, and endocrine systems. Representative tissues from all body systems were collected fresh (and later frozen at $-20^{\circ} \mathrm{C}$ ) and also fixed in formalin for histological examination. Bacteriology tests were performed on blowhole and fecal swabs (Athens Vet Diagnostic $\mathrm{Lab}^{3}$ ) and virological tests were conducted for agents such as herpes virus, influenza, and mobillivirus. Teeth were aged by D. $\operatorname{Vos}^{4}$ and stomach contents were analyzed by the Alaska Department of Fish and Game, Arctic

${ }^{3}$ Mention of trade names or commercial firms does not imply endorsement by the National Marine Fisheries Service, NOAA.

${ }^{4}$ Teeth were aged by Daniel Vos, Anchorage, AK. Growth layer groups are laid down annually in Cook Inlet belugas. 


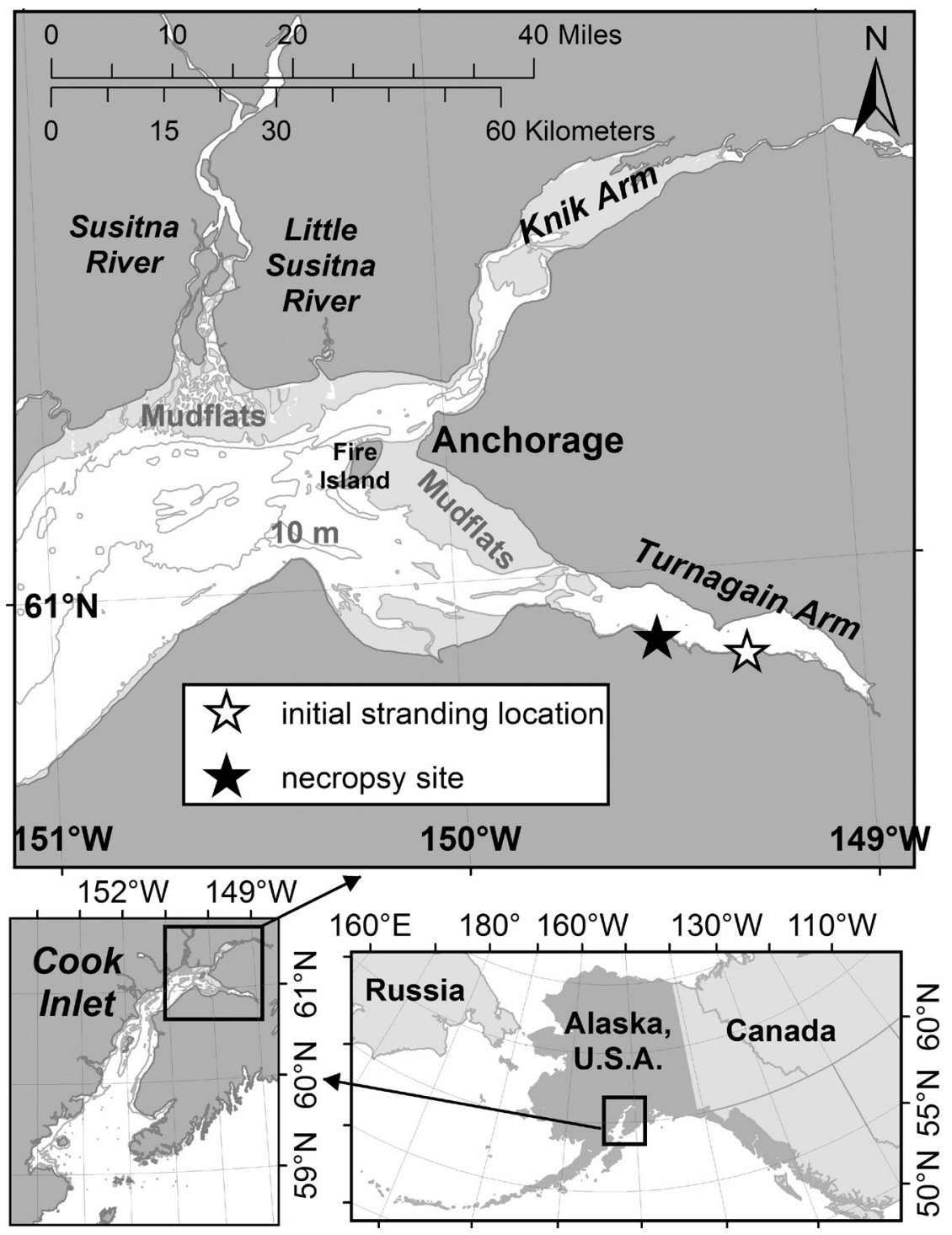

Figure 1.- Initial stranding location and necropsy site for a male beluga whale that died of asphyxiation in Cook Inlet, Alaska, in October 2013.

Marine Mammal Program, Fairbanks, Alaska.

\section{Results}

\section{Gross Findings}

External examination revealed an adult male in good body condition determined by distinct and well-developed "rails" (thick folds of blubber along the ventral surface) as well as internally abundant blubber stores and fat at the base of the heart. The abdomen was markedly bloated and blood was draining from the eye, anus, and preputial opening. The carcass was mildly decomposed and largely intact with minimal scavenging by birds (Fig. 2). This whale was well known, having been identified in photographs every year from 2004 to 2014 (McGuire $^{5}$ ).

A large flatfish was found firmly lodged in the pharynx, near the constriction named the "goose beak." This fish was folded with the head and tail

${ }^{5}$ McGuire, Tamara. LGL Research Associates, Anchorage, AK, Personal commun., 2016. projecting outward and lateral spines down through the esophagus. It could not be easily removed from the mouth outward. It appeared that the fish had displaced the goose beak from the nasopharynx (Fig. 3). Dark red fluid was draining from the blowhole. The tracheal and bronchial mucosa were deeply discolored (from red to black), and covered in granular black to tan material (most likely aspirated food material). Blubber near the ventral midline of the cervical region was markedly discolored, red, and mottled. On cross section, some of these areas had red discoloration radiating outward from the muscle layer. This trauma appeared to be the result of fish spines in the esophagus.

Cause of death was determined to be asphyxiation due to displacement of the goose beak by a starry flounder, Platichthys stellatus (Fig. 4). The flounder appears to have been too large to fit into the pharynx as it was folded to the side of the goose beak and embedded into the esophagus. It could be neither regurgitated nor swallowed because of the direction of the spines and its size and orientation. Further evidence of choking included a large amount of aspirated material, likely digesta, in the lungs.

Other findings, not related to the cause of death, included irregular lymph nodes (the prescapular was irregular and multinodular, and caudal mediastinal and hilar lymph nodes were greatly enlarged and mottled). The liver had autolyzed and the spleen was congested and enlarged. Thyroid and pituitary glands were not examined. The urinary bladder was not observed. The intestines were discolored dark red and there was little content in the sections examined. Multiple, small mineralized nodules $(0.5-2 \mathrm{~cm}$ in diameter) were present in both kidneys (17 in the left, 36 in the right) which contained nematodes, Crassicauda giliakiana. No parasites were observed in the lungs. There were no other significant gross findings.

The stomach was collected intact and contained a Pacific cod, Dadus microcephalus, otolith; Arctic lamprey, 
Lampetra camtschatica, mouth parts; fragments of invertebrates from polychaetes (Polynoidae) and Nereis sp.; and shrimp (Crangonidae); and a few nematodes.

\section{Histopathologic and Ancillary Findings}

Laboratory results of blowhole swabs were negative for influenza virus, but positive for beluga herpesvirus. Beluga herpesvirus is endemic in Cook Inlet beluga whales (BurekHuntington et al., 2015; Davison et al., 2017) and does not cause symptoms in healthy animals and no symptoms (e.g., skin lesions) were observed. There was some intermyofiber fibrosis in the heart, particularly the left ventricle. This has been seen quite frequently in older belugas and appears to be a change that comes about as the animal ages. Subsequent aging of the teeth determined that this whale was a $40 \mathrm{yr}$ old adult $\left(\mathrm{Vos}^{4}\right)$. The prescapular lymph node was in good histologic condition and did show a pyogranu-

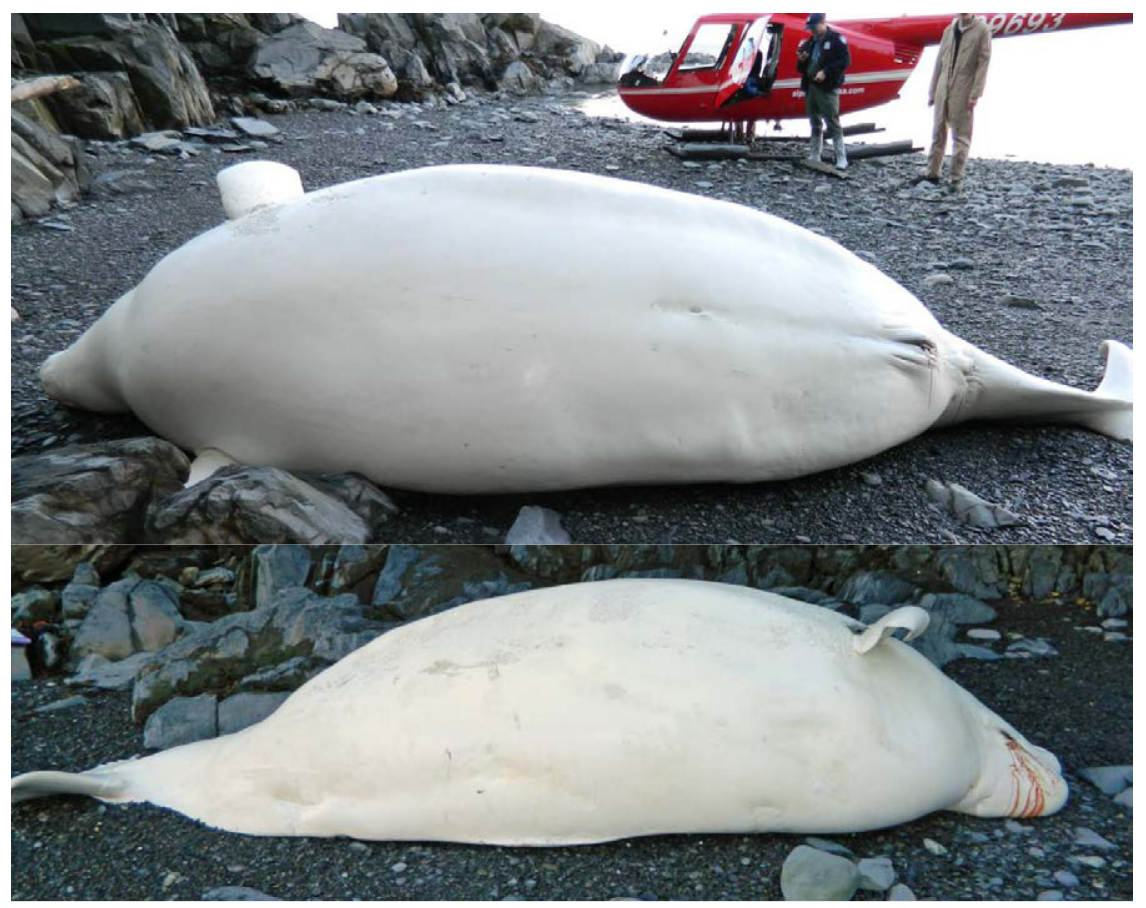

Figure 2.- Ventral and dorsal surfaces of the male beluga whale (2013-CIB-04) prior to start of the necropsy.

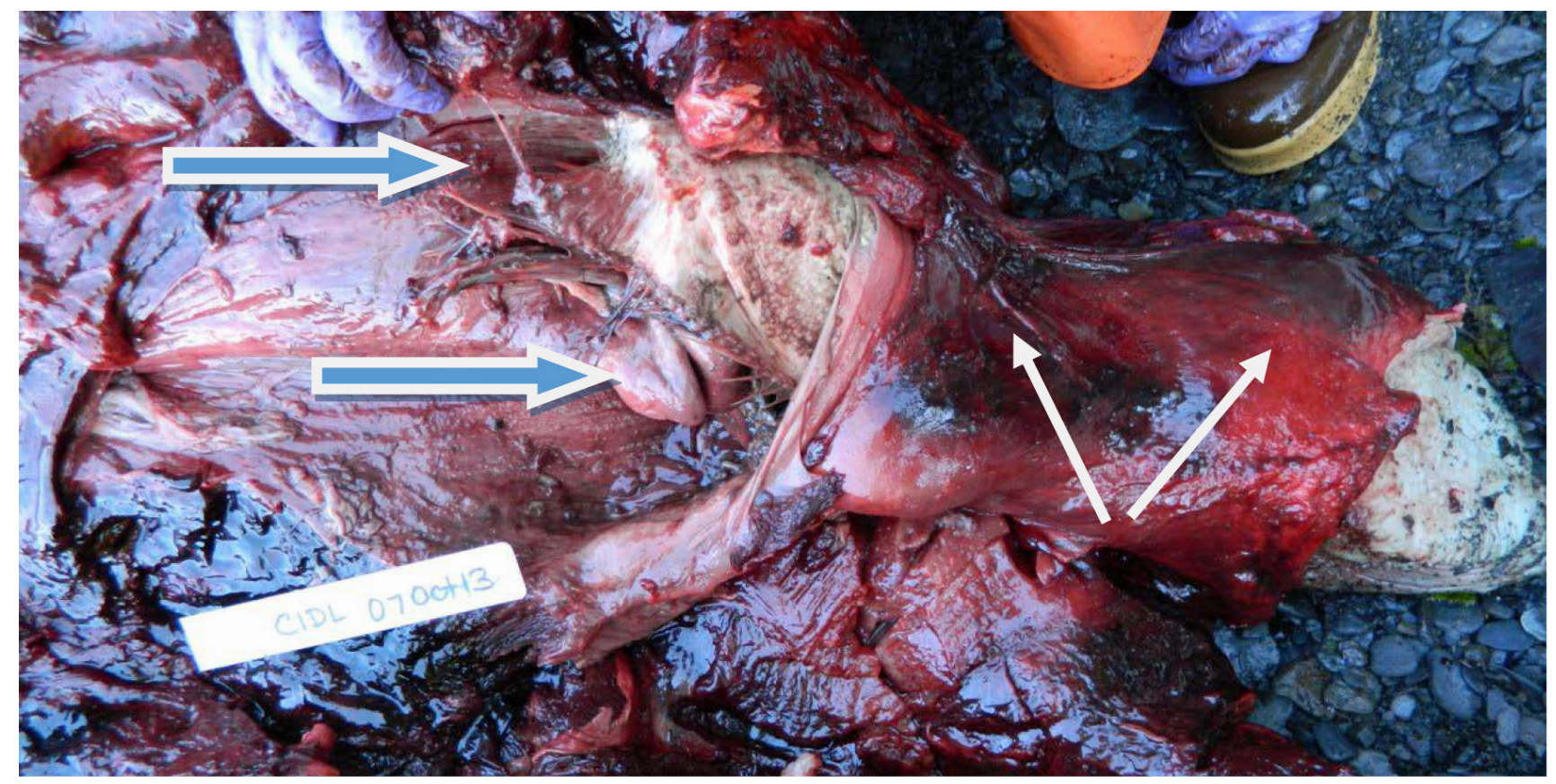

Figure 3.- Internal damage caused by displacement of the goose beak during ingestion of a flounder by a male beluga whale (2013-CIB-04). Solid arrows (on right) indicated the ventral hemorrhage in the esophagus. Open arrows (at left) indicate the goose beak and position of the flounder. 

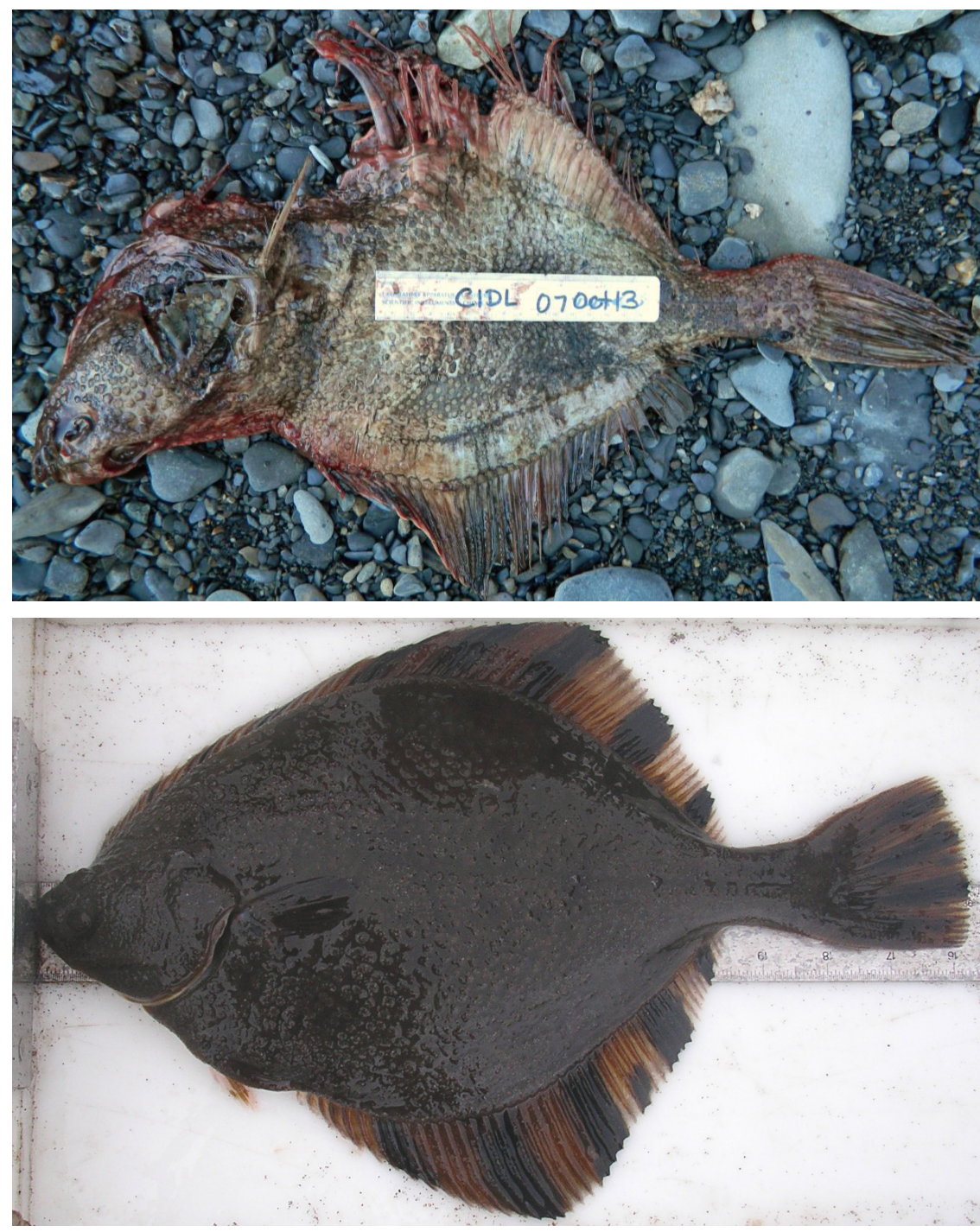

Figure 4.-Top: starry flounder, Platichthys stellatus, ingested by the male beluga whale (2013-CIB-04). Bottom: comparison image of an intact starry flounder (source: https://alaskafisheries.noaa.gov/habitat/nearshore-fish-photos, and https://alaskafisheries.noaa.gov/mapping/oreZoneMvcServicesBeta/FishAtlas/ FishDisplayPage?spCode=FLOUNST accessed 1 Apr. 2017).

lomatous lymphadenitis of unknown cause. It was most likely related to drainage from subcutaneous parasites or from the chronic lesion seen in the neck.

There was extensive inflammation associated with the submucosal glands in the esophagus and some chronic fibrosis in skeletal muscle in the area at the site of the obstruction, which was chronic and active. It is possible that this chronic fibrosis and abnormalities amount of debris, including some skeletal muscle (possibly fish), corroborating that some food had been aspirated into the lungs. Overall, there was nothing within the histopathologic findings to indicate another cause of death other than asphyxiation.

\section{Discussion}

In cetaceans, the anatomy of the esophagus and the trachea are completely separate and no air is inhaled through the mouth. The esophagus is bifurcated by a cartilaginous extension of the trachea called the goose beak (Fig. 5). This cartilaginous organ bridges the gap between the nasal passages and the trachea, and while it is not attached, it is tightly fitted within the animal, and designed to keep anything but air out of the lungs. The goose beak can be dislocated if the animal swallows something too large to pass through the bifurcation.

Asphyxiation due to laryngeal displacement has been documented in cetaceans, most often in bottlenose dolphins, Tursiops truncatus (Harmer, 1927; Johnston and Ridgway, 1969; Berrow and Rogan, 1997; Bossart et al., 2003; Watson and Gee, 2005; Mazzoil et al., 2008; Mignucci-Giannoni et al., 2009; Stolen et al., 2013; Barros and Odell ${ }^{6}$ ) and T. aduncus (Byard et al., 2003, 2010; Kemper et al., 2005). Choking on prey has also been reported for other wild cetacean species such as long-finned pilot whales, Globicephala melas ((IJsseldijk et al., 2015); harbor porpoise, Phocoena phocoena (Orr, 1937; Scheffer and Slipp, 1948; Scheffer, 1953; Hult et al., 1980); Pacific white-sided dolphins, Lagenorhynchus obliquidens (Houck, 1961); short-beaked common dolphin, Delphinus delphis (Krivokhizhin and Birkun, 1991); Atlantic spotted dolphin, Stenella frontalis (Mignucci-Giannoni, 1996); whitebeak dolphin, L. albirostris (Scottish Agriserved; however, there were frequent, occasionally mineralized, Splendorehoeppli bodies lining the bronchi and bronchioles. This feature is often associated with lung worms in belugas (Burek-Huntington et al., 2015). A few bronchi in the lungs contained a large
${ }^{6}$ Barros, N. B., and D. K. Odell. 1995. Preyinduced mortality in coastal bottlenose dolphins from the southeastern United States. In Abstracts of XX reunión internacional para el estudio de los mamíferos marinos. La Paz, Baja Calif. Sur, Méx., p. 54. 
cultural College ${ }^{7}$ ); and minke whale, Balaenoptera acutorostrata (Knowles, 2000).

Cook Inlet beluga hunters recall a time "a beluga was found thrashing around in shallow water with a flounder stuck in its throat" (Huntington, 2000). We know of only one other circumstance of asphyxiation in a wild beluga, an animal that attempted to ingest a 20 lb. (9.1 kg) cod (Fay, 1971). Fay (1971) noted that fish larger than 9 lb. (4.1 kg) were rarely consumed. Salmon were the largest fish found in beluga stomachs examined by Quakenbush et al. (2015), and none were larger than $7.7 \mathrm{lb}(3.5 \mathrm{~kg})$. Asphyxiation has occurred in captive belugas (Hult et al., 1980; Casey, 2015) and Pacific white-sided dolphins (Ridgway and Johnston, 1965), and is a known concern for captive beluga whales that may also ingest toys or other foreign objects (Woodie ${ }^{8}$ ).

Watson et al. (2015) theorized that death due to asphyxiation is caused by ingestion of extra-large or unusual prey such as small sharks (Harmer, 1927; Orr, 1937). Barros and Odell ${ }^{6}$ suggest ingesting prey with "dangerous" appendages such as dorsal or pectoral spines could be a risk factor. Although this starry flounder falls into the typical length of prey (17-64 $\mathrm{cm}$ ) consumed by Cook Inlet belugas (Quakenbush et al., 2015) it is an unusually shaped prey item in that it is a wide flatfish with prominent spines on two edges (Fig. 4). In addition to spines, flatfish may have a harder backbone due to their unique anatomy, making them less flexible when swallowed (IJsseldijk et al., 2015). IJsseldijk et al. (2015) documented fatal asphyxiations in two long-finned pilot whales caused by another flatfish, the common sole, Solea solea.

Due to this beluga's excellent body condition, and both chronic and acute

\footnotetext{
${ }^{7}$ Scottish Agricultural College. 2000. Cetacean strandings investigation Scotland Project report to the then Dep. Environ., Transport Regions, CR0179, Inverness, Scotl., 67 p. (cited in Mignucci-Giannoni et al. (2009)).

${ }^{8}$ Woodie, Derek. Marine mammal trainer, Alaska SeaLife Center, Seward, AK, Personal commun., 2015.
}
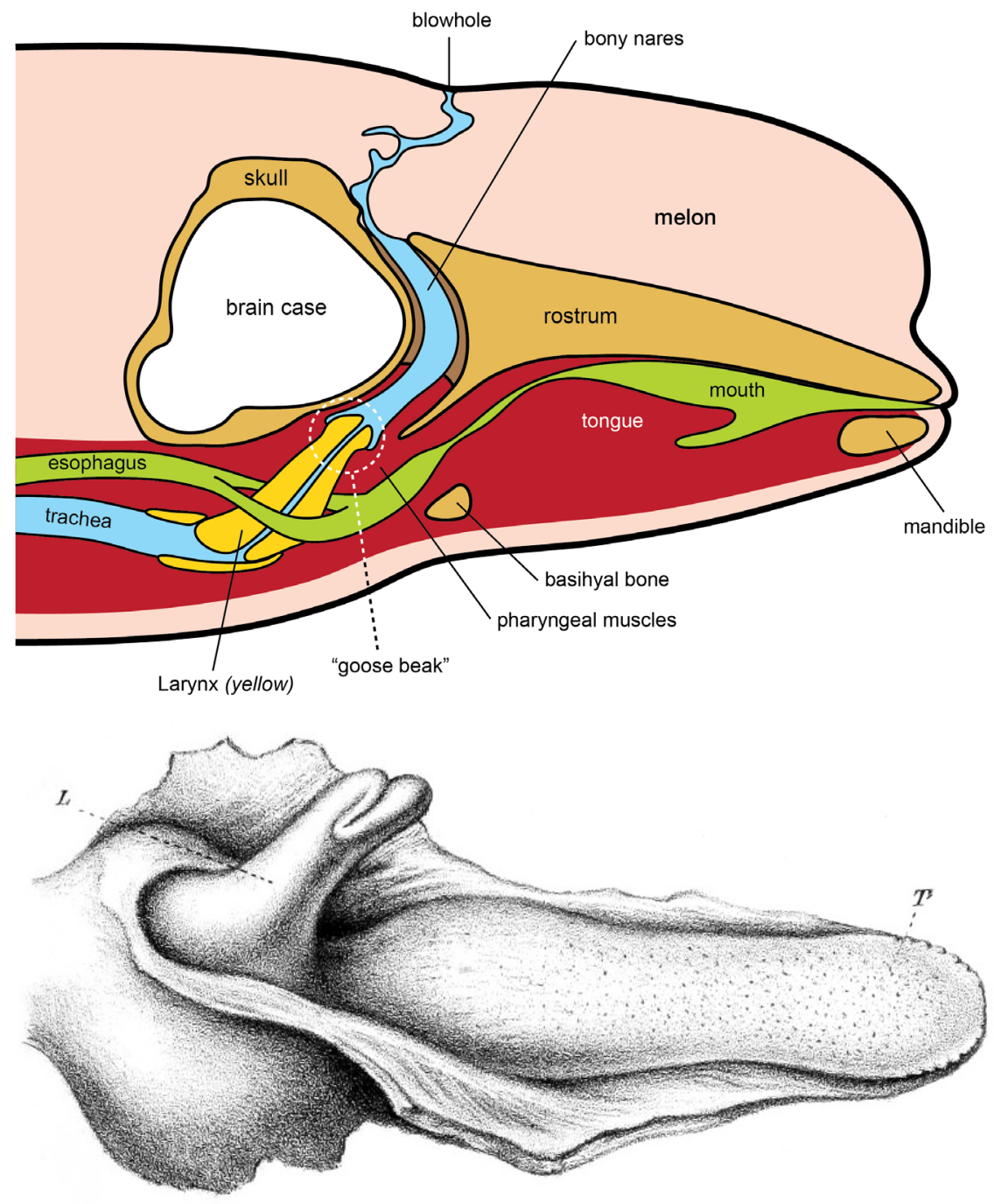

Figure 5.- Schematic of the respiratory and gastrointestinal tract of a beluga showing the location of the goose beak (illustration by Uko Gorter) above, and scientific illustration, below, showing the tongue $(\mathrm{T})$ and larynx $(\mathrm{L})$ from Watson and Young (1880).

wounds in the larynx, consuming flatfish may have been a repeated behavior for this particular animal that ended fatally in this instance. Starry flounder, as well as other flatfish species, are known prey items for Cook Inlet and western arctic beluga whales (Fay, 1971; Quakenbush et al., 2015) and may have been the preferred prey of this individual whale during the fall (when it died) following the end of anadromous fish runs in the inlet. While we do not consider asphyxiation during feeding to be related to the de- cline of the Cook Inlet beluga population, it is nonetheless noteworthy and demonstrates the need to document causes of death through necropsies, when possible, for these critically endangered whales.

\section{Acknowledgments}

The Anchorage Regional Office of the National Marine Fisheries Service, provided funding and logistic support as part of the stranding response plan ${ }^{2}$ for Cook Inlet. Samples were collected under NMFS Research 
Permit 932-1905-00/MA-009526 under the Marine Mammal Health and Stranding Response Permit and also funded by Prescott Grant NA12NMF4390162. We thank D. Vos for aging the teeth and L. Quakenbush (Alaska Department of Fish and Game) for stomach content data. This manuscript was greatly improved by review comments from two anonymous reviewers.

\section{Literature Cited}

Berrow, S. D., and E. Rogan. 1997. Review of cetaceans stranded on the Irish coast, 190195. Mammal Rev. 27:51-76. (doi: https://doi. org/10.1111/j.1365-2907.1997.tb00372.x).

Bossart, G. D., R. Meisner, R. Varela, M. Mazzoil, S. D. McCulloch, D. Kilpatrick, R. Friday, E. Murdoch, B. Mase, and R. H. Defran. 2003. Pathologic findings in stranded Atlantic bottlenose dolphins (Tursiops truncatus) from the Indian River Lagoon, Florida. Fla. Sci. 66(3):226-238.

Burek-Huntington, K. A., J. L. Dushane, C. E. C. Goertz, L. N. Measures, C. H. Romero, and S. A. Raverty. 2015. Morbidity and mortality in stranded Cook Inlet beluga whales Delphinapterus leucas. Dis. Aquat. Org. 114:45-60. (doi: https://doi.org/10.3354/ dao02839).

Byard, R. W., J. D. Gilbert, S. E. Gibbs, and C. M. Kemper. 2003. Cetacean café coronary. J. Clinic. Forensic Med. 10:85-88. (doi: https:// doi.org/10.1016/S1353-1131(03)00009-9).

I. Tomo, C. M. Kemper, S. E. Gibbs, M. Bossley, A. Machado, and M. Hill. 2010. Unusual causes of fatal upper aerodigestive tract obstruction in wild bottlenose dolphins (Tursiops aduncus). Forensic Sci. Med. Pathol. 6(3):207-210. (doi: https://doi. org/10.1007/s12024-010-9143-3).

Casey, S. 2015. Voices in the ocean: a journey into the wild and haunting world of dolphins. Doubleday, N.Y., 320 p.

Davison, A. J., O. Nielsen, K. Subramaniam, J. M. Jacob, C. H. Romero, K. A. Burek-Huntington, and T. B. Waltzek. 2017. Genome sequence of an alphaherpesvirus from a beluga whale (Delphinapterus leucas). Genome Announcements 5:e01100-01117.

Fay, F. H. 1971. Belukha, Arctic white whales. In A. Seed (Editor), Toothed whales in the eastern North Pacific and arctic waters, p. 23-27. Pac. Search Press, Seattle, Wash.

Harmer, S. F. 1927. Report on cetacea stranded on the British coasts from 1913 to 1926 . British Museum (Nat. Hist.), Rep. 10, Lond., 91 p.
Hobbs, R. C., D. J. Rugh, and D. P. DeMaster 2000. Abundance of belugas, Delphinapterus leucas, in Cook Inlet, Alaska, 1994-2000. Mar. Fish. Rev. 62(3):37-45.

K. E. W. Shelden, D. J. Rugh, C L. Sims, and J. M. Waite. 2015. Estimated abundance and trend in aerial counts of beluga whales, Delphinapterus leucas, in Cook Inlet, Alaska, 1994-2012. Mar. Fish. Rev. 77(1):11-31. (doi: https://doi.org/10.7755/ MFR.77.1.2)

Houck, W. J. 1961. Notes on the Pacific striped porpoise. J. Mammal. 42:107. (doi: https:// doi.org/10.2307/1377264).

Hult, R. W., S. E. Dupey, and R. W. Badley. 1980. Mortalities associated with prey ingestion by small cetaceans. Cetology 38:1-2.

Huntington, H. P. 2000. Traditional knowledge of the ecology of belugas, Delphinapterus leucas, in Cook Inlet, Alaska. Mar. Fish. Rev. 62(3):134-140.

IJsseldijk, L. L., M. F. Leopold, E. L. B. Rebolledo, R. Deaville, J. Haelters, J. IJzer, P. D. Jepson, and A. Gröne. 2015. Fatal asphyxiation in two long-finned pilot whales (Globicephala melas) caused by common soles (Solea solea). PLoS ONE 10(11) e0141951. (doi: https://doi.org/10.1371/jour nal.pone.0141951)

Johnston, D. G., and S. H. Ridgway. 1969. Parasitism in some marine mammals. J. Am. Vet Med. Assoc. 155:1064-1072.

Kemper, C. M., A. Flaherty, S. E. Gibbs, M Hill, M. Long, and R. W. Byard. 2005. Cetacean captures, strandings and mortalities in South Australia 1881-2000, with special reference to human interactions. Austral. Mammal. 27:37-47. (doi: https://doi.org/10.1071/ AM05037)

Knowles, S. 2000. A whale of a story: Marine mammals and sea turtles in Maryland. The Maryland Nat. Resourc. 10 (Spring).

Krivokhizhin, S. V., and A. A. Birkun, Jr. 1991. Death of a dolphin due to asphyxia after the aspiration of fish. Veterinaria (Moscow) N11:53-54.

Laidre, K. L., K. E. W. Shelden, D. J. Rugh, and B. A. Mahoney. 2000. Beluga, Delphinapterus leucas, distribution and survey effort in the Gulf of Alaska. Mar. Fish. Rev. 62(3):27-36.

Mazzoil, M. S., S. D. McCulloch, M. J. Youngbluth, D. S. Kilpatrick, E. M. Murdoch, B. Mase-Guthrie, D. K. Odell, and G. D. Bossart. 2008. Radio-tracking and survivorship of two rehabilitated bottlenose dolphins (Tursiops truncatus) in the Indian River Lagoon, Florida. Aquat. Mammals 34(1):54-64. (doi: https://doi.org/10.1578/ AM.34.1.2008.54).

Mignucci-Giannoni, A. A. 1996. Marine mammal strandings in Puerto Rico and the United States and British Virgin Islands. Ph.D. Dissert., Univ. Puerto Rico, Mayagüez, 184 p.
R. J. Rosario-Delestre, M. M. A1sina-Guerrero, L. Falcón-Matos, L. GuzmánRamírez, E. H. Williams Jr, G. D. Bossart, and J. S. Reidenberg. 2009. Asphyxiation in a bottlenose dolphin (Tursiops truncatus) from Puerto Rico due to choking on a black margate (Anisotremus surinamensis). Aquat. Mammals 35(1):48-54. (doi: https://doi. org/10.1578/AM.35.1.2009.48).

O’Corry-Crowe, G. M., R. S. Suydam, A. Rosenberg, K. J. Frost, and A. E. Dizon. 1997. Phylogeography, population structure and dispersal patterns of the beluga whale Delphinapterus leucas in the western Nearctic revealed by mitochondrial DNA. Mol. Ecol. 6:955-970. (doi: https://doi. org/10.1046/j.1365-294X.1997.00267.x).

Orr, R. T. 1937. A porpoise chokes on a shark. J. Mammal. 10:370. (doi: https://doi. org/10.1093/jmammal/18.3.370).

Quakenbush, L. T., R. S. Suydam, A. L. Bryan, L. F. Lowry, K. J. Frost, and B. A. Mahoney. 2015. Diet of beluga whales, Delphinapterus leucas, in Alaska from stomach contents, March-November. Mar. Fish. Rev. 77(1):7084. (doi: https://doi.org/10.7755/MFR.77.1.7

Ridgway, S. H., and D. G. Johnston. 1965. Two interesting disease cases in wild cetaceans. Am. J. Vet. Res. 112:771-775.

Rommel, S. A., A. M. Costidis, A. Fernandez, P. D. Jepson, D. A. Pabst, W. A. McLellan, D. S. Houser, T. W. Cranford, A. L. Vanhelden, D. M. Allen, and N. B. Barros. 2006. Elements of beaked whale anatomy and diving physiology and some hypothetical causes of sonarrelated stranding. J. Cetacean Res. Manag. 7(3):189-209.

Scheffer, V. B. 1953. Measurements and stomach contents of eleven delphinids from the Northeast Pacific. Murrelet 34:27-30. (doi: https://doi.org/10.2307/3535867). and J. W. Slipp. 1948. The whales and dolphins of Washington State with a key to the cetaceans of the west coast of North America. Am. Midland Nat. 39:257-337. (doi: https://doi.org/10.2307/2421587).

Stolen, M., J. S. Leger, W. N. Durden, T. Mazza, and E. Nilson. 2013. Fatal asphyxiation in bottlenose dolphins (Tursiops truncatus) from the Indian River Lagoon. PLoS ONE 8(6):e66828. (doi: https://doi.org/10.1371/ journal.pone.0066828)

Watson, A., and L. E. Gee. 2005. Laryngeal displacement and asphyxiation by a beheaded sheepshead (Archosargus probatocephalus) in a bottlenose dolphin (Tursiops truncatus). Aquat. Mammals 31(4):447-452. (doi: https://doi.org/10.1578/AM.31.4.2005.447).

Watson, M., and A. H. Young. 1880. The anatomy of the northern beluga (Beluga catodon, Gray; Delphinapterus leucas, Pallas) compared with that of other whales. Trans. R. Soc. Edinb. 29:393-435, pl. 7-8. 